\title{
Factors influencing the use of food storage structures by agrarian communities in Northern Uganda
}

\author{
Charles Owach ${ }^{a *}$ \\ Food and Agriculture Organization of the United Nations \\ Godfrey Bahiigwa ${ }^{\mathrm{b}}$ \\ International Food Policy Research Institute \\ Gabriel Elepu ${ }^{c}$ \\ Makerere University
}

Submitted April 21, 2016 / Revised July 6, August 28, October 12, November 18, and

November 23, 2016 / Accepted November 23, 2016 / Published online February 23, 2017

Citation: Owach, C., Bahiigwa, G., \& Elepu, G. (2017). Factors influencing the

use of food storage structures by agrarian communities in northern Uganda.

Journal of Agriculture, Food Systems, and Community Development, 7(2), 127-144.

http://dx.doi.org/10.5304/jafscd.2017.072.003

Copyright (C) 2017 by New Leaf Associates, Inc.

\begin{abstract}
Food storage at the national or global level is important due to its multifunctional roles of enhancing food access, nutrition, and income security at the national, community and household levels. This study assesses the importance of food storage structures and their utilization by farmers cultivating finger millet (Eleusine coracana) and common beans (Phaseolus vulgaris) in Apac and Arua districts, Northern Uganda. The study encom-
\end{abstract}

a * Corresponding author: Charles Owach, Food and Agriculture Organization of the United Nations; P.O. Box 521; Kampala, Uganda; +256-776-487079 or +256-772-487079;

Charles.Owach@,fao.org

b Godfrey Bahiigwa, Office Head, International Food Policy Research Institute, Eastern and Southern Africa Regional Office; ILRI Campus, P.O. Box 5689; Addis Ababa, Ethiopia; g.bahiigwa@cgiar.org

c Gabriel Elepu, Department of Agribusiness \& Natural Resource Economics, Makerere University; P.O. Box 7062; Kampala, Uganda; elepu@caes.mak.ac.ug passed a total sample of 782 households producing finger millet and/or beans (388 of which were below and 394 above the poverty line). A binary probit regression analysis was used to identify the factors influencing the household use of improved storage structures.

The findings indicated that only $22 \%$ of households used improved storage structures and that usage depended on the age of the household

\footnotetext{
Author Notes

This paper was developed from Charles Owach's Ph.D. thesis submitted in fulfillment of the requirements for the award of a doctorate degree at Makerere University, Kampala, Uganda.

This research is an assessment of the extent of use of improved food storage structures in two districts in Northern Uganda and associated factors that are associated with influencing storage use. The two districts covered (Apac and Arua) represent the two farming systems in Northern Uganda, that is, Northern and West Nile farming systems. The analysis was undertaken for households above and below the poverty line in order to guide policy decision-making.
} 
head, education level of the household head, membership in a farmer group or association, family size, and distance to market. The findings also indicate that the postharvest policies of the past did not have any significant effect on household access to improved storage technologies in the study areas. It is generally agreed that usage of improved storage structures leads such benefits as postharvest losses reduction, product quality conservation and increased duration of storage (World Food Programme [WFP], 2015). Thus we suggest that strategies to improve the usage of improved storage structures may be organizing agrarian communities and reaching them with carefully developed postharvest programs. This action could lead to higher usage rates of these technologies in this region.

\section{Keywords}

Food Losses; Improved Storage Structures; Postharvest Losses; Agrarian; Households; Poverty; Smallholder; Northern Uganda

\section{Introduction and Literature Review}

Globally, about one-third (or 1.3 billion tons) of total food products, valued at almost US\$1 trillion, is lost or wasted annually, almost one-half of which is from developing countries (Food and Agriculture Organization of the United Nations [FAO], 2011). In sub-Saharan Africa (SSA), food loss accounts for $30 \%$ of total crop production and amounts to about US $\$ 4$ billion a year (World Bank, 2011). This value exceeded the value of total food aid received by ${ }^{1}$ SSA for the decade 1998-2008 and equals the value of all cereal imports to SSA in the period 2000-2007 (The World Bank, 2011). Postharvest food losses contribute greatly to food, nutrition, and income insecurity in this region.

\footnotetext{
${ }^{1}$ According to the United Nations Millenium Project website, "The Millennium Development Goals (MDGs) are the world's time-bound and quantified targets for addressing extreme poverty in its many dimensions-income poverty, hunger, disease, lack of adequate shelter, and exclusion-while promoting gender equality, education, and environmental sustainability. They are also basic human rights— the rights of each person on the planet to health, education, shelter, and security" (United Nations, n.d., para. 2). The first goal is to eradicate extreme hunger and poverty.
}

While some SSA nations have made some improvements in achieving the Millennium Development Goals ${ }^{1}$ by decreasing the share of their populations suffering from extreme poverty (hunger), $41 \%$ (25\%) of the SSA population is still reported to be extremely poor (undernourished) (FAO, 2015; United Nations [UN], 2015). Since expenditures on food uses up much of household income in SSA and most residents depend on agriculture and allied activities as their source of income, the impact on food security and poverty of reducing food losses could be immense (Chauvin, Mulangu, \& Porto, 2012). The objective of this paper was to assess the use of food storage systems for households cultivating Eleusine coracana and Phaseolus vulgaris in Apac and Arua districts of Northern Uganda as a strategy for reducing food loss.

Much of these losses in SSA take place at the early stages of the food supply chain, and can be attributed mainly to both pre- and postharvesting losses (Kereth, Lyimo, Mbwana, Mongi, \& Ruhembe, 2013). On-farm storage of food crops such as grains is commonly done by households using traditional storage structures (ThamagaChitja, Hendriks, Ortmann, \& Green, 2004). In eastern and southern parts of Africa, a wide variety of storage structures are used, including wire cribs, polythene bags, and metal silos (Kankolongo, Hell, \& Nawa, 2009) (see Figures 1-3).

The postharvest losses of highly perishable food products such as fruits and vegetables, livestock and fishery products are even higher than for grains, and is attributable primarily to lack of cold chain (continuous cooling system for a commodity), poor processing facilities, and marketing infrastructure (Hodges, Buzby, \& Bennett, 2011). Reducing food losses by investing in improved and user-friendly postharvest management offers opportunities for enhancing food security and household incomes in SSA without incurring any additional production costs (Hodges et al., 2011). Improving postharvest management techniques can also help build resilience against current and future climate-related shocks and reduce the need for expanding farmland and damage to environmental services, including carbon sequestration (Stathers, Lamboll, \& Mvumi, 2013). 


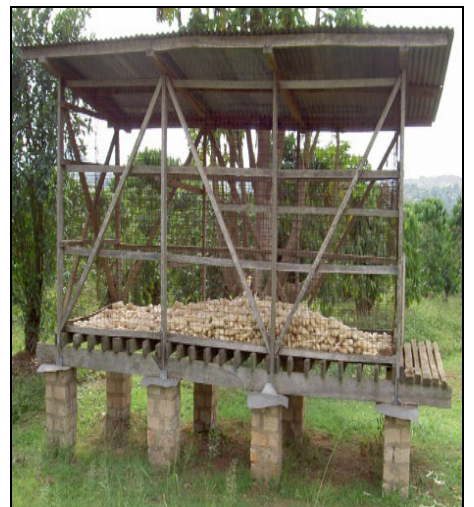

Figure 1. Wire Crib

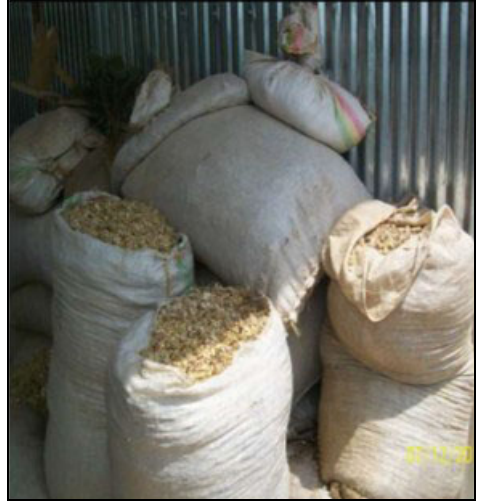

Figure 2. Polythene Bags

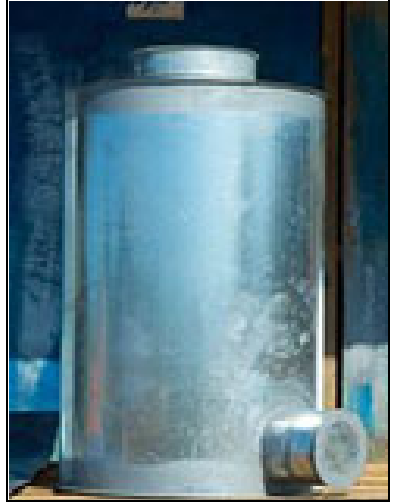

Figure 3. Metal Silo
In addition to building capacity of smallholder farmers in postharvest management, both hermetic and nonhermetic storage technologies have been introduced and tested for efficacy in a number of SSA countries (WFP, 2015). These storage technologies have proven to be effective in reducing food losses. Some of these technologies include super grain bags, zero fly bags, plastic silos, metal silos, grain safes, and improved granaries (Figures 4-8). Such structures were tested by farmers in Uganda and Burkina-Faso and found to be effective in reducing postharvest food losses by $98 \%$, regardless of the crop and duration of storage (WFP, 2015).

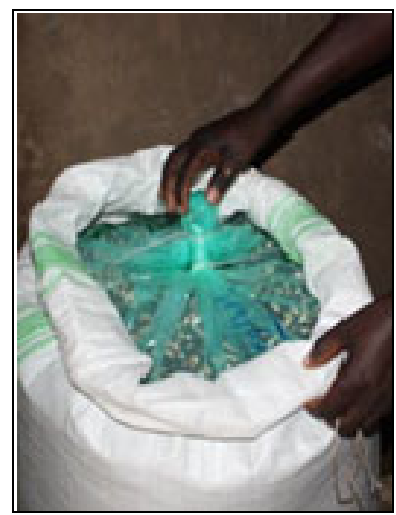

Figure 4. Super Grain Bag

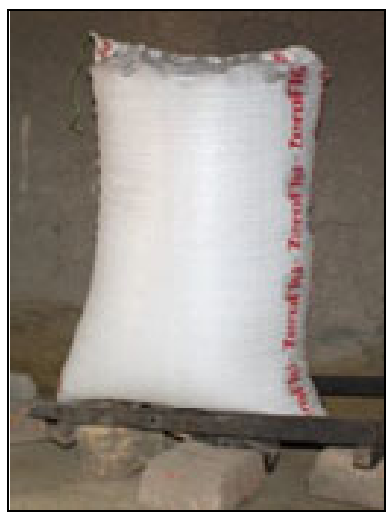

Figure 5. Zero Fly Bag

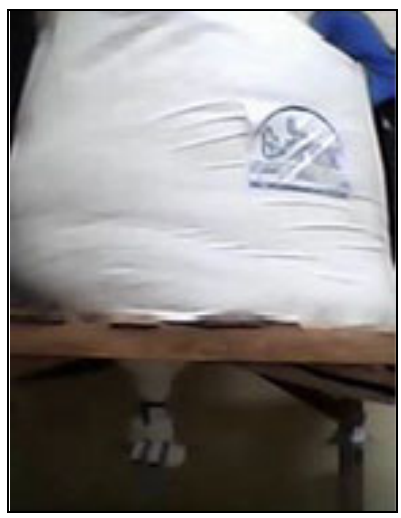

Figure 7. Grain Safe

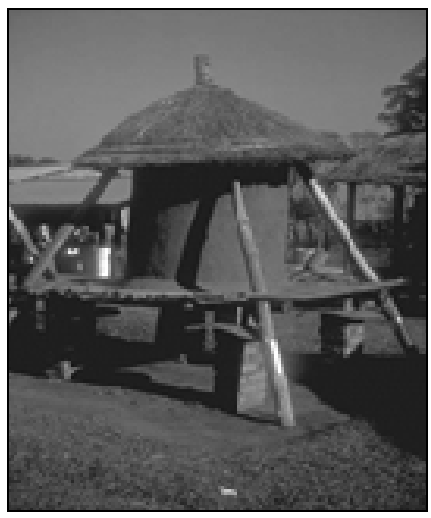

Figure 8. Improved Granary 
A number of projects related to food storage innovations have attempted to link smallholder farmers to markets and credit institutions as ways to boost their incomes (Bouquet Wampfler, \& Ralison, 2009; Coulter \& Onumah, 2002; KENFAP, 2011; United States Agency for International Development-Livelihoods and Enterprises for Agricultural Development [USAID-LEAD], 2012; Woomer \& Mukhwana, 2004). Such initiatives have used a participatory approach, as in the case of maize in rural areas of Kenya (Woomer \& Mukhwana, 2004) and rice in Madagascar and Tanzania (Coulter \& Onumah, 2002). Smallholders in several African countries, such as Niger, Madagascar, Zambia, Malawi, Kenya, and Uganda, have also participated directly in donor-funded inventory credit or "warrantage" system for grains (Bouquet et al., 2009). Similar to the above strategies is the warehouse receipt system also introduced to many countries in eastern and southern Africa (Coulter \& Onumah, 2002). Smallholders in SSA are in one way or the other willing to adopt improved structures for postharvest technologies at the household level. This indicates that there is considerable potential for these smallholders to participate directly in collective storage at the community and national levels.

The adoption rate for improved grain storage technologies among smallholder farmers in SSA at the household level, however, is variable $(12.7 \%-$ $74 \%$ ), with most studies indicating adoption rates below 50\% (Aguessy, 2009, as cited in Affognon, Mutungi, Sanginga, \& Borgemeister, 2015; Arouna, Adegbola, \& Biaou, 2011; Moussa, LowenbergDeBoer, Fulton, \& Boys, 2011). Some studies have reported abandonment rates as high as $56 \%$ to 73\% (Adegbola, 2010; Affognon, Mutungi, Sanginga, \& Borgemeister, 2015). Other studies reported adoption rates of $12.7 \%$ for metal drums used for storage of cowpea in Benin (Moussa et al., 2011); $40.9 \%$ adoption of improved granaries for maize storage in Benin (Arouna et al., 2011); adoption rates in Benin of $74 \%, 45 \%$, and $41 \%$ for wooden granaries for storing maize cobs, and for metal cans and polyethylene bags for storage of grains, respectively (Aguessy, 2009, as cited in Affognon et al., 2015). With an adoption rate of improved storage structures of only $5 \%$, farmers in Benin seems to have the lowest adoption rates, yet when storage technologies are developed using participatory approaches, adoption rates of $80 \%$ were reported (Affognon et al., 2015). In Tanzania, a $55 \%$ to $64 \%$ uptake rate of extension knowledge on control of larger grain borer by farmers was recorded (Golob, 1991). However, the rate of adherence to using such structures by the farmers was only $17 \%$. This could be attributed to various socio-economic factors, such as inadequate capital for the high costs of the technologies, limited technical know-how, and low price variability between seasons, which reduces returns to storage (Affognon et al., 2015; Golob, 1991).

Moreover, there is growing evidence indicating low levels of participation among smallholders in collective storage (Ton, de Grip, Lançon, Onumah, \& Proctor, 2014). In Uganda, only 23\% of existing capacity of certified warehouses was utilized in 2011 , with a majority (90\%) of the grain depositors being traders; some warehouses did not have a single farmer registered to participate (USAIDLEAD, 2012). The low utilization of the storehouses was attributed mainly to their poor location, lack of trust in the storage management arrangements (including bad memories by farmers of the functioning of some cooperatives in the past), and unfavorable terms of storage for the farm produce (e.g., a lack of cash advances to farmers at the time of farm commodity deposit, even though farmers often need cash for domestic and social needs) (USAID-LEAD, 2012). The same situation applies to Kenya, where $90 \%$ of warehouse grain deposits were from large-scale farmers and traders, leaving only $10 \%$ of the space to smallholder farmer groups, a situation due mainly to high storage fees and the relatively small volumes of commodities offered by small farmers, even as farmer groups Jones \& Lowenberg-DeBoer, 2014; KENFAP, 2011).

Various reasons have been attributed to poor utilization of scientific postharvest management technologies by smallholder farmers in SSA. As indicated in a review by Affognon et al. (2015), the problems can be associated with technological, socio-cultural, economic, and political reasons. Poor delivery of the scientific innovations, lack of knowledge of modern conservation methods or 
techniques by many SSA smallholder farmers, and inappropriate postharvest technologies have been given as some of the reasons efforts to minimize food losses have been hindered (Bediako, Chianu, \& Dadson, 2009; Obeng-Ofori, 2011). Results from a study in Tanzania reported that $96 \%$ of farmers have limited knowledge of methods of proper postharvest management (Abass, Ndunguru, Mamiro, Alenkhe, Mlingi, \& Bekunda, 2014). Smallholder farmers also may stick to traditional techniques of food conservation for fear of venturing into scientifically new but locally untested methods available from research stations. Winniefridah and Manuku (2013) reported that the people of Matabeleland in the southern province of Zimbabwe preferred traditional ways of storage to modern ways involving the use of agro chemicals due to health concerns. The cost of constructing improved storage structures has also hindered their accessibility to farmers (Jones \& LowenbergDeBoer, 2014). Furthermore, stringent quality and quantity requirements associated with conservation methods are a constraint for many farmers, as is the case with the warehouse storage system (Onumah, 2010).

In Uganda, postharvest interventions by public, private, and development partners, such as the Marketing and Agro-processing Strategy (MAPS) formulated in 2004, have attempted in the past to promote the use of improved storage structures at the household level by building the capacity of farmers in postharvest loss management and demonstrations on improved storage technologies (cribs, silos, etc.) (Republic of Uganda, Ministry of Agriculture, Animal Industry and Fisheries [MAAIF], 2012a). However, postharvest food losses are still high, as exemplified by the grains sector having $15-30 \%$ loss, attributable to the use of poor postharvest handling and storage technologies by farmers (Republic of Uganda, MAAIF, 2012a). A study by Ssewanyana and Kasirye (2010) indicated that appropriate postharvest storage technologies and conservation methods are important in coping up with seasonal fluctuations in household dietary intakes. Yet Ssewanyana and Kasirye (2010) did not examine household usage of improved storage structures or technologies for conserving agricultural and food products. Better understanding of the types of storage structures and factors influencing the use of improved storage structures are important as they can support evidence-based decision-making and policy formulation, and contribute to attaining household food security.

\section{Materials and Methods}

\section{The Study Area}

The study covered two districts in Northern Uganda: Apac (longitude $32.15^{\circ}-32.95^{\circ} \mathrm{E}$ and latitude $1.65^{\circ}-2.25^{\circ} \mathrm{N}$ ) and Arua (longitude $30.75^{\circ}-$ $31.50^{\circ} \mathrm{E}$ and latitude $2.50^{\circ}-3.35^{\circ} \mathrm{N}$ ). Apac and Arua were selected as sample districts for a number of reasons. They are major food-producing districts and have long-standing peace and security. Apac and Arua belong to the Northern and West Nile farming systems, respectively. Apac and Arua districts encompass key commercial towns (of the same names) in Northern Uganda; this provides good market conditions for price arbitrage. Apac and Arua districts' human development index $(\mathrm{HDI})^{2}$ of 0.508 and 0.551 in 2005 were $13 \%$ and $5 \%$, respectively below the national average of 0.581 (UNDP, 2007). The overall HDI for the Northern region in 2005 was 0.499 , which was $14.1 \%$ lower than the national average of 0.581 during the same year (UNDP, 2007). Considering some of the factors described above, Apac and Arua districts were considered to be representative of the Northern region. Furthermore, interregional comparisons indicate that the Northern region continues to lag behind in many socioeconomic indicators (Republic of Uganda, Ministry of Finance, Planning and Economic Development [MFPED], 2014). The proportion of the population living in poverty in this region is still high at $43.7 \%$ (2012/13); while an improvement from $60.7 \%$ in $2005 / 06$, it is high compared to the overall national poverty levels of $19.7 \%$ and $31.1 \%$ in 2012/13 and 2005/06, respectively (MFPED,

\footnotetext{
2 The HDI is a holistic measure of overall human progress, with special emphasis on living a decent life. It is an index comprising three components that reflect the ends of the development effort: life expectancy index, education index, and GDP index, all weighted by one-third to obtain the HDI.
} 
2014). This region experiences recurrent food insecurity problems; expenditures on food were as high as $56 \%$ of all rural household expenditures in Northern Uganda in 2012/13 (MFPED, 2014).

The choice of finger millet (Eleusine coracana) and common bean (Phaseolus vulgaris) was informed by the fact that they are among the main staples of the people in Apac and Arua districts. Mukiibi (2001) lists the main crops grown in Northern Uganda as being cassava (Manihot esculentus), maize (Zeamays), finger millet, sorghum (Sorghum bicolor), cowpeas (Vigna unguiculata), groundnuts (Arachis bypogaea), pigeon peas (Cajanus cajan), rice (Oryza sativa), common beans (Phaseolus vulgaris), sweet potatoes (Ipomea batatas), sunflower (Helianthus annuus), soybeans (Glycine max), and cotton (Gossypium species). In addition to contributing to food security, finger millet and beans are easily storable, with lower post-harvest losses and lower perishability than fruits, vegetables, meat, and fish (Hodges, Buzby, \& Bennett, 2011).

\section{Data and Sampling Techniques}

In this study, we analyzed data collected in the Uganda census of agriculture 2008/09 by the Uganda Bureau of Statistics (UBOS). UBOS used a stratified two-stage sample design to select small and medium-scale households. The first stage involved the selection of Enumeration Areas (EAs) with probability proportional to size (PPS) in the study districts. The second stage involved the selection of households (ultimate sampling units) using systematic sampling, after stratification based on acres of cropland (UBOS, 2010a). The optimal number of 10 households (respondents) were selected per EA (resulting in samples of 57 and 52 in Apac and Arua districts, respectively) based on cost ratio and intra-class correlation. After exploratory data analysis, the pooled sample size for the two study districts used in the analysis was 782 households.

Households were categorized into two groups: those above and those below the Northern region's poverty line. The national poverty line was equivalent to UGX 62,545 (approximately US $\$ 34.00$; US $\$ 1=1,840$ UGX at the time of this study) per adult equivalent per month; the northern region rural poverty line was UGX 54,174.47
(US\$29.40) per adult equivalent per month in 2008/09, considering the reference (base) period of 2005/06 (UBOS, 2013). From the total sample size of 782 households, 394 households were above the poverty line and 388 households were below the poverty line. Data analyzed included storage types for food grains; age, sex, and education level of the household head; income status of the household (above or below the poverty line); whether an extension worker had visited the household; the household's access to credit; location variable (district where the household was located); and household size, standardized in terms of how many adult-equivalents are in each family. Household adult equivalencies were based on nutritional requirements using consumption conversion factors as recommended and contained in the World Health Organization's (1985) nutrition guidelines.

Continuous variables (age of household head, number of years of formal education of household head, household size, and household income) were measured at variable mean using t-statistics (Table 1). Categorical variables (sex of household head, access of household head to extension and credit services, and membership of household head in a farmer group or association) were measured as percentages using $\left(\chi^{2}\right)$ (Table 1).

Analysis of the storage structures used by households involved two steps. First, from the UBOS census 2008/09 dataset we identified and analyzed the various types of storage structures and households using them using frequency distributions. This was followed by categorizing the use of various storage structures into two broad categories (i.e., households using improved storage facility $=1$; households using unimproved storage $=0$ ), after consulting with UBOS (the data source) and postharvest specialists. ${ }^{3}$

\section{Data Analysis}

STATA12 statistical software was used for data analysis. Analysis of household use of improved

\footnotetext{
${ }^{3}$ Key: Improved storage facility $=1$; unimproved storage facility $=0$. Improved granary $=1$; Unimproved granary $=0$; In the house $=0$; Specific house $/ \mathrm{room}=1$; Under shelter outside $=0$; Cribs $=1$; Silos $=1$; Cold storage $=1$; Underground $=0$; Over fireplace $=0$; Sealed containers $=1$; Others $=0$.
} 
Table 1. Characteristics of Households Growing Finger Millet and Bean in Apac and Arua Districts, 2008/09

\begin{tabular}{|c|c|c|c|c|c|c|c|}
\hline \multirow[b]{2}{*}{ Characteristics } & \multicolumn{2}{|c|}{$\begin{array}{l}\text { Households above } \\
\text { poverty line }\end{array}$} & \multicolumn{2}{|c|}{$\begin{array}{l}\text { Households below } \\
\text { poverty line }\end{array}$} & \multirow{2}{*}{$\begin{array}{c}\text { All } \\
\text { households } \\
\text { above poverty } \\
\text { line }\end{array}$} & \multirow{2}{*}{$\begin{array}{c}\text { All } \\
\text { households } \\
\text { below } \\
\text { poverty line }\end{array}$} & \multirow{2}{*}{$\begin{array}{l}\text { Overall } \\
\text { sample }\end{array}$} \\
\hline & Apac & Arua & Apac & Arua & & & \\
\hline & \multicolumn{7}{|c|}{ Standard deviations in parentheses } \\
\hline Age of household head (years) & $\begin{array}{c}43.2 \\
(15.4)\end{array}$ & $\begin{array}{c}46.6 \\
(20.8)\end{array}$ & $\begin{array}{c}43.7 \\
(11.7)\end{array}$ & $\begin{array}{l}46.3^{* *} \\
(13.3)\end{array}$ & $\begin{array}{c}44.8 \\
(18.2)\end{array}$ & $\begin{array}{c}44.7 \\
(12.4)\end{array}$ & $\begin{array}{c}44.8 \\
(15.6)\end{array}$ \\
\hline $\begin{array}{l}\text { Education of household head } \\
\text { (years in school) }\end{array}$ & $\begin{array}{c}6.2 \\
(2.8)\end{array}$ & $\begin{array}{l}6.0 \\
(3.3)\end{array}$ & $\begin{array}{c}5.9 \\
(3.9)\end{array}$ & $\begin{array}{l}5.7 \\
(4.5)\end{array}$ & $\begin{array}{c}6.2 \\
(3.0)\end{array}$ & $\begin{array}{l}5.8 \\
(4.2)\end{array}$ & $\begin{array}{l}6.0 \\
(3.6)\end{array}$ \\
\hline $\begin{array}{l}\text { Household size (adult } \\
\text { equivalent) }\end{array}$ & $\begin{array}{c}3.3 \\
(2.0)\end{array}$ & $\begin{array}{l}3.0 \\
(1.6)\end{array}$ & $\begin{array}{l}5.4 \\
(1.9)\end{array}$ & $\begin{array}{l}5.8 \\
(2.8)\end{array}$ & $\begin{array}{c}3.1 \\
(1.9)\end{array}$ & $\begin{array}{l}5.6^{* * *} \\
(2.3)\end{array}$ & $\begin{array}{c}4.3 \\
(2.3)\end{array}$ \\
\hline $\begin{array}{l}\text { Household income (UGX per } \\
\text { capita per month) }\end{array}$ & $\begin{array}{c}69,527 \\
(12,771)\end{array}$ & $\begin{array}{c}70,956 \\
(13,278)\end{array}$ & $\begin{array}{c}39,726 \\
(11,785)\end{array}$ & $\begin{array}{c}37,293 \\
(14,528)\end{array}$ & $\begin{array}{r}70,185 \\
(13,004)\end{array}$ & $\begin{array}{l}38,710^{* * *} \\
(13,038)\end{array}$ & $\begin{array}{r}52,253 \\
(20,312)\end{array}$ \\
\hline $\begin{array}{l}\text { Sex of household head: } \\
\text { Male (\%) }\end{array}$ & 73.0 & 75.9 & 85.4 & 79.0 & 74.4 & $82.7^{* * *}$ & 78.5 \\
\hline $\begin{array}{l}\text { Household access to } \\
\text { extension services (\%) }\end{array}$ & 29.0 & $6.4^{* * *}$ & 45.6 & $9.3^{* * *}$ & 18.3 & $30.4^{* * *}$ & 24.3 \\
\hline $\begin{array}{l}\text { Household access to credit } \\
(\%)\end{array}$ & 5.3 & 2.7 & 7.1 & $15.4^{* * *}$ & 4.1 & $10.6^{* * *}$ & 7.3 \\
\hline $\begin{array}{l}\text { Membership in farmer group } \\
\text { or association (\%) }\end{array}$ & 15.0 & $3.2^{* * *}$ & 25.2 & $13.0^{* * *}$ & 9.4 & $20.1^{* * *}$ & 14.7 \\
\hline
\end{tabular}

$* * * p<.01 ; * * p<.05$

Note: The significance levels relate to comparisons across rows. Source: Uganda Bureau of Statistics, 2010b.

storage structures was done using the probit model developed following the utility theory as suggested by Greene (1997). The probit model makes it possible to generate the marginal effects of the explanatory variables on the probability of adoption, and the model has been used to establish factors affecting adoption (Lapar \& Pandey, 1999; Pindyek \& Rubinfeld, 1991). The model presupposes that the decision by the household to adopt or use or not to adopt or use improved storage system would depend on an unobservable index $Z_{i}$ determined by explanatory variables, where the bigger the index, the greater the probability of the household to use improved storage system.

The expression takes the form:

(1) $Z_{i}=\alpha+\beta_{i} X_{i}$

Where:

$X_{i}=$ Number of years of formal education of head of household, as an example;

$\alpha$ and $\beta_{i}=$ parameters to be estimated.

Considering a dummy variable with values 1 (if household adopts or uses improved storage system); 0 if not using, and assuming an unobservable threshold for $Z_{i}=Z_{i}^{*}$, the household would adopt or use improved storage if $Z_{i}$ exceeds $Z_{i}^{*}$, Assuming $Z_{i}^{*}$ is also normally distributed like $Z_{i}$, the parameters of the index $Z_{i}$ can be estimated and information about it obtained, and the values of $\alpha$ and $\beta_{i}$ can be obtained. Information on $Z_{i}$, $\alpha$, and $\beta_{i}$ was obtained by taking the inverse of equation (1); hence,

(2) $Z_{i}=A^{-1}\left(Z_{i}\right)=A^{-1}\left(P_{i}\right)=\alpha+\beta_{i} X_{i}+e$

Where:

$Z_{i}=$ Household decision to use or not to use improved storage system ( $1=$ household uses improved storage system; 0 does not use); $\alpha=$ Constant; $X_{i}=$ Vector of explanatory variables; $\beta_{i}=$ Vector of parameters to be estimated; $e=$ Error term

The specification of the probit analytical model was as in equation (3) below. 
(3)

$$
Z_{i}=\alpha+\beta_{1} X_{1}+\beta_{2} X_{2} \ldots+\beta_{9} X_{9}+e
$$

Where:

$Z_{i}=$ Dicotomous variable $(1=$ use of improved storage system; $0=$ Otherwise) $\alpha=$ Intercept; $X_{1}=$ Age of household head (years); $X_{2}=$ Sex of household head (Male $=1$; Female $=0) ; X_{3}=$ Education of household head (years); $X_{4}=$ Poverty line (Above $=1$; Below $=0) ; X_{5}=$ Extension visit $(Y e s=1$; $\mathrm{No}=0) ; X_{6}=$ Membership in farmer group or association (Yes $=1 ; \mathrm{No}=0) ; X_{7}=$ Obtained credit $(\mathrm{Yes}=1 ; \mathrm{No}=0) ; X_{8}=$ District $(\mathrm{Apac}=1$; Arua $=0) ; X_{9}=$ Household size (Adult equivalent); $e=$ Error term

\section{Results and Discussion}

\section{Characteristics of Households}

Almost three-quarters of households studied were male-headed. Overall, there was no significant difference in age and education level of respondents below and above the poverty level (Table 1). Irrespective of the type, household access to extension services, credit, and membership in farmer groups or associations were generally low in Apac and Arua districts (Table 1). Households below the poverty line were more likely $(p<0.01)$ to access extension and credit services and to be in organized farmer groups or associations than those above the poverty line (Table 1). Households in Apac district had better access to extension services and were more likely to be members of farmer groups compared to those in Arua district, while those in Arua had better access $(p<0.01)$ to credit services (Table 1). Better access by farmers to extension services in Apac may be attributed to the greater proportion of farmers being in groups, which facilitates extension outreach and adoption of improved technologies (Table 1), in line with results of a study on farmer field schools in Uganda (Lwala, Elepu, \& Hyuha, 2016).

In the study districts, extension service delivery was provided mainly by National Agricultural Advisory Services (NAADS). This agency categorized farmers on the basis of their food security, with $70 \%$ as subsistence farmers, $25 \%$ as semicommercial, and 5\% as commercial farmers
(MAAIF, 2012b). The main objective of subsistence farmers is food security (consuming over $50 \%$ of their own production); semicommercial farmers sell at least $50 \%$ of their production, while commercial farmers grow sugarcane, tea, rice, oil palm, and coffee mainly on large-scale, specialized estates and sell the whole of their production after processing (MAAIF, 2012b).

Results of the Uganda census of agriculture indicate that only $10 \%$ of the agricultural households countrywide accessed credit during the period 2002/03 to 2007/08 (UBOS, 2010b). The main source of credit was self-help groups (village savings loan associations), which provided loans to $30.8 \%$ of households; microfinance institutions (MFIs), which provided loans to $28.7 \%$ of households; and families and friends, who provided loans to $17.6 \%$ of households (UBOS, 2010b). Banks provided loans to only $10.3 \%$ of agricultural households (UBOS, 2010b). Self-help groups, MFIs, and families and friends provided the majority of loans to subsistence farmers and semicommercial farmers; banks provided loans to commercial farmers (UBOS, 2010b). With up to $76 \%$ of households required to provide collateral as security for loans, the need for collateral was the main constraint to accessing loans by agricultural households (UBOS, 2010b). The main forms of collateral provided by farmers were land titles (29.1\%), character $(23.1 \%)$, crops (19.0\%), and livestock (16.7\%) (UBOS, $2010 \mathrm{~b})$. Organizing famers into groups and associations is being done by primarily by development actors and government programs such as NAADS in order to enhance their access to agricultural extension services and credit (MAAIF, 2012b).

\section{Household Production and Storage of Finger Millet and Beans}

Results displayed in Table 2 indicate that respondents above the poverty line produced higher quantities of finger millet and beans compared to their counterparts below the poverty line, mainly due to ownership of more agricultural land and better financial resources to hire farm labor. The average land size was 2.2 ha (5.4 acres) and 1.18 ha ( 2.92 acres) for households above and below the poverty line, respectively (UBOS, 2010b). On average, households above the poverty line stored 
Table 2. Per Capita Seasonal Finger Millet and Bean Production and Storage in Apac and Arua Districts, 2008/09 (in kg)

\begin{tabular}{|c|c|c|c|c|c|c|c|}
\hline \multirow[b]{2}{*}{ Crop } & \multicolumn{2}{|c|}{$\begin{array}{l}\text { Households above } \\
\text { poverty line }\end{array}$} & \multicolumn{2}{|c|}{$\begin{array}{l}\text { Households below } \\
\text { poverty line }\end{array}$} & \multirow{2}{*}{$\begin{array}{c}\text { All } \\
\text { households } \\
\text { above } \\
\text { poverty line }\end{array}$} & \multirow{2}{*}{$\begin{array}{c}\text { All } \\
\text { households } \\
\text { below } \\
\text { poverty line }\end{array}$} & \multirow{2}{*}{$\begin{array}{l}\text { Overall } \\
\text { sample }\end{array}$} \\
\hline & Apac & Arua & Apac & Arua & & & \\
\hline \multicolumn{8}{|l|}{ Finger Millet } \\
\hline Quantity produced & 85.5 & $265.8^{* * *}$ & 62.7 & $196.1^{\text {** }}$ & 214.9 & $106.1^{* *}$ & 152.3 \\
\hline Quantity stored & 30.2 & $78.7^{* *}$ & 15.5 & $29.0^{* *}$ & 55.2 & $20.4^{* * *}$ & 39.2 \\
\hline \multicolumn{8}{|l|}{ Beans } \\
\hline Quantity produced & 66.5 & $401.2^{* * *}$ & 34.5 & 53.7 & 202.9 & $42.6^{* * *}$ & 116.6 \\
\hline Quantity stored & 18.4 & $62.9^{* * *}$ & 8.5 & 18.1 & 35.5 & $12.0^{* * *}$ & 22.9 \\
\hline
\end{tabular}

$* * * p<.01 ; * * p<.05$

Notes: The significance levels relate to comparisons across rows; $1 \mathrm{~kg}=2.2 \mathrm{lbs}$.

Source: Uganda Bureau of Statistics, 2010b.

Table 3. Types of Storage Structures Used by Households in Apac and Arua Districts (\%), 2008/09

\begin{tabular}{|c|c|c|c|c|c|c|c|}
\hline \multirow[b]{2}{*}{ Storage type } & \multicolumn{2}{|c|}{$\begin{array}{l}\text { Households above } \\
\text { poverty line }\end{array}$} & \multicolumn{2}{|c|}{$\begin{array}{l}\text { Households below } \\
\text { poverty line }\end{array}$} & \multirow{2}{*}{$\begin{array}{c}\text { All } \\
\text { households } \\
\text { above } \\
\text { poverty line }\end{array}$} & \multirow{2}{*}{$\begin{array}{c}\text { All } \\
\text { households } \\
\text { below } \\
\text { poverty line }\end{array}$} & \multirow{2}{*}{$\begin{array}{l}\text { Overall } \\
\text { sample }\end{array}$} \\
\hline & Apac & Arua & Apac & Arua & & & \\
\hline Improved granary & $7.8 \%$ & $0 \%$ & $4.4 \%$ & $0 \%$ & $3.7 \%$ & $2.2 \%$ & $2.9 \%$ \\
\hline Unimproved granary & 19.6 & 35.3 & 47.0 & 33.9 & 28.0 & 40.3 & 34.4 \\
\hline Inside house & 70.3 & 64.6 & 60.5 & 81.5 & 67.2 & 71.2 & 69.4 \\
\hline $\begin{array}{l}\text { Inside specific house or } \\
\text { room }\end{array}$ & 15.7 & 11.5 & 18.3 & 25.0 & 13.5 & 21.7 & 17.8 \\
\hline Under shelter outside & 0 & 6.2 & 4.3 & 11.7 & 3.3 & 8.1 & 5.8 \\
\hline Cribs & 1.0 & 0 & 0 & 2.5 & 0.5 & 1.3 & 0.9 \\
\hline Over fireplace & 2.9 & 20.2 & 6.1 & 21.5 & 12.1 & 14.0 & 13.1 \\
\hline Sealed containers & 1.9 & 10.1 & 0 & 6.6 & 6.3 & 3.4 & 4.8 \\
\hline Others & 0 & 1.7 & 0 & 4.1 & 0.9 & 2.1 & 1.5 \\
\hline
\end{tabular}

Source: Uganda Bureau of Statistics, 2010b.

$55.2 \mathrm{~kg}(121.7 \mathrm{lb}$.$) of finger millet and 35.5 \mathrm{~kg}(78.3$ lb.) of beans per capita per season, while those below the poverty line stored $20.4 \mathrm{~kg}(45.0 \mathrm{lb}$.) of finger millet and $12.0 \mathrm{~kg}(26.5 \mathrm{lb}$.) of beans per capita per season. Households in Arua district produced and stored larger quantities of finger millet and beans compared to those in Apac district (Table 2); this may be attributed to more intensive farming and generally richer soils in Arua than in Apac (UBOS, 2010b).

\section{Types of Storage Structures Used}

As indicated in Table 3, the two most common storage structures used by households were within the residence of the farmers (69.4\%) and in unim- proved granary $(34.4 \%) .{ }^{4}$ The majority of households below the poverty line $(>71 \%)$ and above the poverty line $(67 \%)$ stored the finger millet and beans in one of the rooms inside the house they were living in: on the floor (Figure 9), in polythene bags (Figure 2), in pots (Figure 10), and in other places. About $18 \%$ of households overall stored grain in a dedicated room of the house they were living in or a dedicated house; the rate varied between households below (22\%) and above (14\%) the poverty line (Table 3; Figure 11).

A primary reason for the common practice of

\footnotetext{
${ }^{4}$ The sum is over $100 \%$ due to some households reporting multiple storage types.
} 


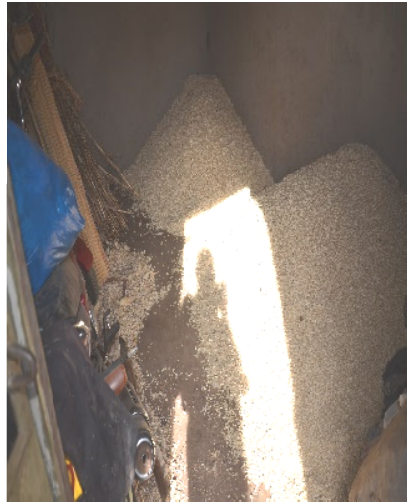

Figure 9. Storing Grain on an Open Floor Inside a House

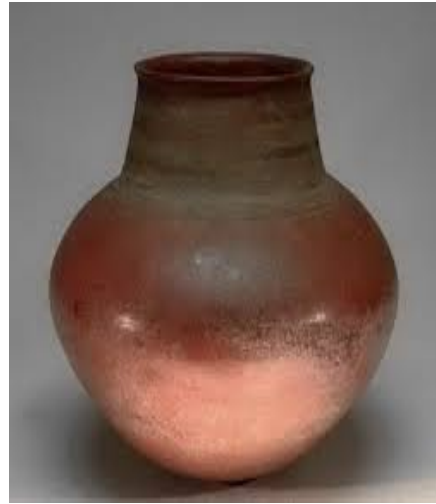

Figure 10. A Clay Pot Used for Storing Grain Inside a House

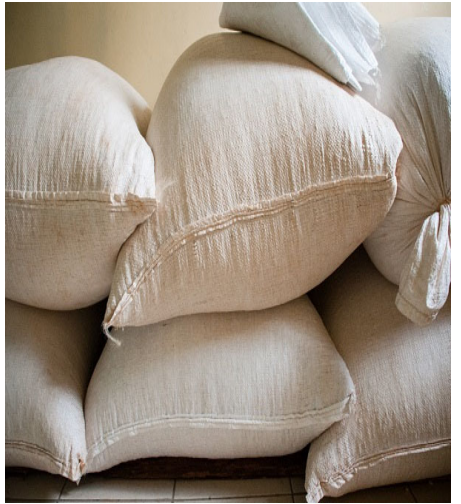

Figure 11. Storing Grain in a Dedicated Room in a House storing grain inside a house is to minimize risks such as postharvest losses from predators, pests, and theft (UBOS, 2010b). Less than 3\% of households used improved granary structures overall, with households above the poverty level using them at the slightly higher rate of $3.7 \%$ (Table 3). An improved granary is a storage structure that is substantially raised off the ground (by about 1 meter or 3.3 feet) and supported by poles fitted with rodent guards, as shown in Figure 8, which sits on concrete blocks and has walls made of mud and wattle and a top made of reeds covered with grass. An unimproved granary is a structure not substantially raised off the ground (about 0.3 meters or a foot off the ground), with the structure sitting on poles or low stones or poles not fitted with rodent guards, as shown in Figure 12, with walls made of mud and wattle and a top made of reeds and covered with grass. The contents of the unimproved granary are prone to attack by rodents, leading to higher postharvest losses. A lower rate among households of improved granary usage for storage may be attributed to the higher cost of building them, as has been found in previous studies (Adegbola, 2010, cited in Affognon et al., 2015).

Furthermore, a few households stored their food products above the fireplace (4.8\%) and in sealed containers in their homes (13.1\%) (Table 3). One type of sealed container is a plastic silo (Figure 6). Most of the respondents who stored food in sealed containers were those who were above the poverty line. This suggests that they were fully aware of the advantages of such containers in guarding against postharvest losses and were also able to afford them, as indicated in a report by the WFP (2015).

Despite government efforts to promote the use of cribs (an improved storage structure for grains, shown in Figure 1), less than 1\% of

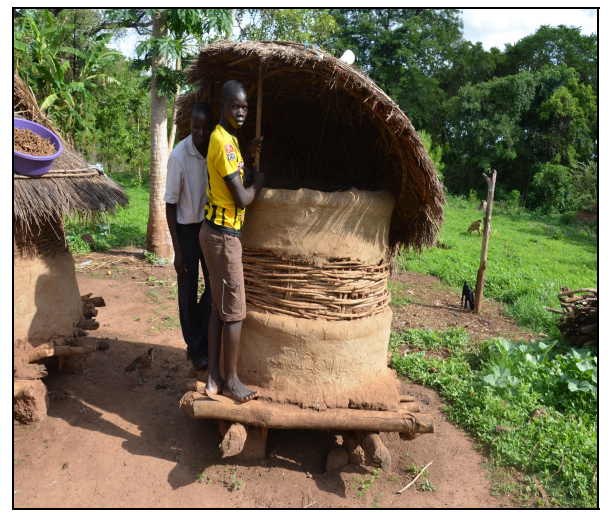

Figure 12. Unimproved Granary

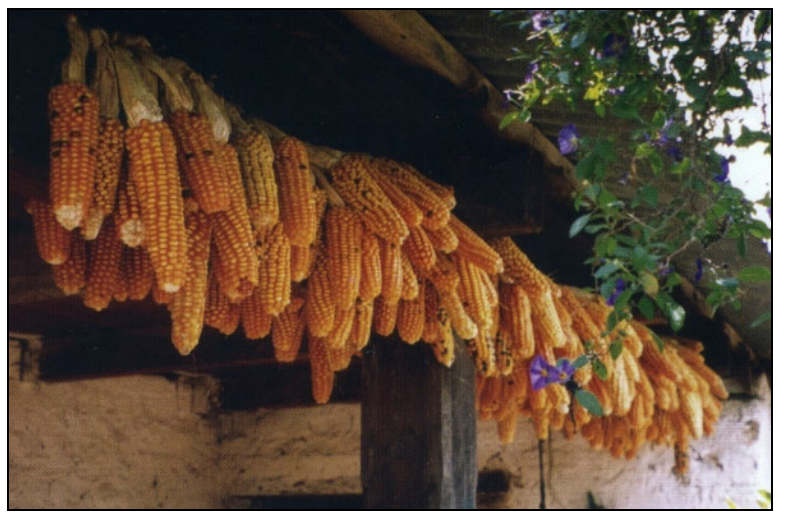

Figure 13. Storage Under Shelter Outside 
households were using the technology (Table 3). This may be attributed, in part, to the low access of extension services by farmers $(24.3 \%)$ as earlier indicated in Table 1 and the high cost of erecting a crib storage facility (Affognon et al., 2015). About $6 \%$ of farmers store food products, usually maize cobs and sorghum, by hanging them outside the house under the veranda, with more farmers in Arua district using the practice compared to those in Apac district (Table 3; Figure 13). This may be due to the greater production of tobacco in Arua, and its use by local farmers as a pest-control substance. Hung together with maize and sorghum under the veranda to dry, tobacco provides protection to maize and sorghum against insect pests, a practice categorized as use of botanicals (indigenous technologies) in pest control in a study by Affognon et al. (2015). Close to 8\% of farmers below the poverty level and 3\% of those above the poverty level reported using this method of storage (Table 3). The higher proportion of the use of this "storage under shelter outside" by farmers below the poverty level compared to those above the poverty level may be attributed to the lower cost of these indigenous methods compared to modern technologies (Affognon et al., 2015).

Results of interviews with various stakeholders revealed that households in the study area generally store crop produce for varying periods, ranging from a week to about six months, for purposes of consumption and sale. These findings are in accordance with results of a study on postharvest food losses in Tanzania, which indicated that the storage period for a number of crops (beans, sesame, groundnuts, sorghum, maize, etc.) ranged from 1 to 6 months (Abass et al., 2014). The major agricultural products usually stored in granaries by respondents in unthreshed forms is cereals, such as finger millet, sorghum, and maize, while legumes (beans, cowpeas, pigeon pea) are usually threshed prior to being stored in houses. Crops normally stored in sealed containers are threshed cowpeas, pigeon peas, and sesame. Selected good-quality maize cobs, finger millet, and sorghum to be used as seed in the coming season are traditionally stored over the fireplace (Thamaga-Chitja et al., 2004).

Storage over the fireplace has some perceived advantage of reducing pest infestation as a result of reduced moisture content for the cereals, and ultimately improving the shelf life of the cereal seeds. Although these perceptions agree with the findings of research conducted in South Africa (A. T. Modi, personal communication, 2003), which indicated that roof-stored seed over the fireplace had more vigor during germination than commercial maize seeds, results of a study by Thamaga-Chitja et al. (2004) indicated lower germination rates and yields from seeds stored over the fireplace. These inconclusive results call for more research in the performance of these storage methods. Finger millet and sorghum were sometimes stored in unthreshed form under shelter outside in areas where households perceive a low risk of theft of these crops. Other storage methods used by households included baskets made from reeds (Figure 14) and underground silos to mention, to mention but a few (UBOS, 2010b).

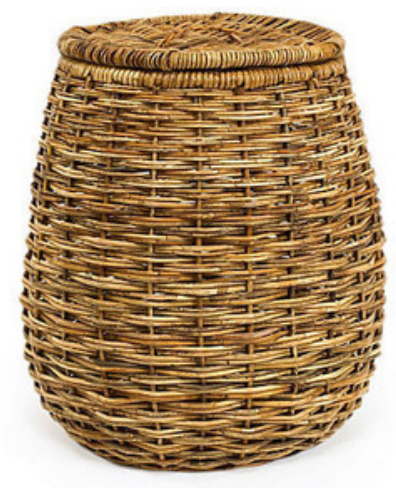

\section{Figure 14. Storage Basket Made from Reeds}

\section{Categories of Storage Structures Used}

The various types of storage structures used by households were categorized into two broad groups: improved and unimproved. To distinguish between improved and unimproved storage structures, the definition of an improved storage structure given by postharvest specialists was used. An improved storage structure is defined as a one "that increases the shelf-life of a given product and maintains its integrity in quantity and quality for a desired period." Improved storage structures included improved granaries, cribs, and storage in a specific house or room. Unimproved storage 
structures included unimproved granaries, houses, under shelter outside, over a fireplace, and sealed containers.

Results showed that a majority $(78 \%)$ of households growing millet and beans still used unimproved storage structures (Table 4). A higher proportion of Apac households below the poverty level $(24.8 \%)$ used improved storage facilities compared to those in Arua district (11.6\%); this may be attributed to the higher per capita income in Apac (Tables 1 and 4). A similar study conducted in Kwara State in Nigeria by Adetunji (2009) indicated that $32 \%$ of farmers used improved storage (semimodern and modern storage techniques). In their review of literature, Affognon et al. (2015) showed that farmer/ household adoption of improved postharvest technologies in SSA varied from $12.7 \%$ to $74 \%$, with most studies reviewed revealing adoption rates of less than $50 \%$. In the same literature, high disadoption rates of $56 \%$ to $73 \%$ were reported in one study. Besides limited access to finance by farmers, the other reasons indicated as causes of low adoption and high disadoption were limited technical know-how, weak innovative delivery systems, and inappropriate technologies (at times) due to inadequate involvement of beneficiaries in selecting technology (Mutambuki \& Ngatia, 2006; Obeng-Ofori, 2011).

\section{Factors Influencing Housebold Use of Improved Storage Structures}

We employed a probit regression technique to assess factors affecting the use of improved storage structures by households in Apac and Arua districts. Results of the probit model are presented in Table 5. Overall, the model fitness and explanatory power for the pooled data for Apac and Arua districts was satisfactory $\left(\mathrm{R}^{2}=0.1155 ; \chi^{2}=46.06\right.$; Prob $\left.>\chi^{2}=0.0000\right)$. Significant variables were age of household head, education of household head, membership in farmer group or association by household head, family size, and distance of the household to the nearest local produce market (Table 5).

Results of analysis of households growing finger millet and beans indicated that the variables age, sex of household head, education level of household head, access to credit, household size, and agricultural land size influenced adoption (use) of improved postharvest structures by varying magnitudes (Table 5). Access to credit by households increased the probability of adoption of improved storage structures by households growing millet and beans by $52 \%$. This may be attributed to credit making it easier for households to purchase the required storage construction materials (poles, wire mesh, etc.) and to hire labor to construct the structures, as corroborated by related postharvest studies in sub-Saharan Africa (Mutambuki \& Ngatia, 2006; Obeng-Ofori, 2011).

An increase in the age of a household head by one year increased the probability of adopting improved storage structure by $43 \%$ for beangrowing households, and by $21 \%$ for households above the poverty line. Similar results were obtained by Maongo, Assa, and Haraman (2013), Okoedo-Okojie and Onemolease (2009), and Lwala et al. (2016). With age comes more experience and resource accumulation, but only to a certain point, when conservativeness or risk aversion to technology adoption is observed.

Table 4. Proportion of Households Growing Finger Millet and Beans Using Improved and Unimproved Storage Structures in Apac and Arua Districts (\%), 2008/09

\begin{tabular}{|c|c|c|c|c|c|c|c|}
\hline \multirow[b]{2}{*}{ Storage type } & \multicolumn{2}{|c|}{$\begin{array}{c}\text { Households above } \\
\text { poverty line }\end{array}$} & \multicolumn{2}{|c|}{$\begin{array}{c}\text { Households below } \\
\text { poverty line }\end{array}$} & \multirow{2}{*}{$\begin{array}{c}\text { All } \\
\text { households } \\
\text { above } \\
\text { poverty line }\end{array}$} & \multirow{2}{*}{$\begin{array}{c}\text { All } \\
\text { households } \\
\text { below } \\
\text { poverty line }\end{array}$} & \multirow{2}{*}{$\begin{array}{l}\text { Overall } \\
\text { sample }\end{array}$} \\
\hline & Apac & Arua & Apac & Arua & & & \\
\hline Improved & 27.1 & 24.8 & 24.8 & $11.6 * * *$ & 26.0 & 17.8 & 21.9 \\
\hline Unimproved & 72.9 & 75.2 & 75.2 & 88.4 & 74.0 & 82.2 & 78.1 \\
\hline Total & 100 & 100 & 100 & 100 & 100 & 100 & 100 \\
\hline
\end{tabular}

$* * * p<.01$

Note: The significance level relates to comparisons across rows.

Source: Uganda Bureau of Statistics, 2010b. 
Table 5. Factors Influencing Household Usage of Improved Storage Structures for Finger Millet and Beans in Apac and Arua Districts, 2008/09

\begin{tabular}{|c|c|c|c|c|c|c|c|c|}
\hline \multirow[b]{2}{*}{ Variable } & $\begin{array}{l}\text { Finger } \\
\text { Millet- } \\
\text { growing } \\
\text { Households }\end{array}$ & $\begin{array}{l}\text { Bean- } \\
\text { growing } \\
\text { Households }\end{array}$ & $\begin{array}{l}\text { Millet and } \\
\text { Bean- } \\
\text { growing } \\
\text { Households }\end{array}$ & $\begin{array}{l}\text { Above } \\
\text { Poverty } \\
\text { Line }\end{array}$ & $\begin{array}{l}\text { Below } \\
\text { Poverty } \\
\text { Line }\end{array}$ & Apac & Arua & $\begin{array}{l}\text { Apac and } \\
\text { Arua }\end{array}$ \\
\hline & \multicolumn{8}{|c|}{ Marginal effects } \\
\hline $\begin{array}{l}\text { Age of household head } \\
\text { (years) }\end{array}$ & $\begin{array}{l}0.06 \\
(0.15)\end{array}$ & $\begin{array}{l}0.43 * * * \\
(0.12)\end{array}$ & $\begin{array}{l}-0.13 \\
(0.09)\end{array}$ & $\begin{array}{l}0.21 * * \\
(0.09)\end{array}$ & $\begin{array}{l}0.14 \\
(0.11)\end{array}$ & $\begin{array}{l}0.20 \\
(0.12)\end{array}$ & $\begin{array}{l}0.16 \\
(0.10)\end{array}$ & $\begin{array}{l}0.18 * * * \\
(0.07)\end{array}$ \\
\hline $\begin{array}{l}\text { Sex of household head } \\
\text { (Male) }\end{array}$ & $\begin{array}{l}-0.49 * * \\
(0.21)\end{array}$ & $\begin{array}{c}0.13 \\
(0.10)\end{array}$ & $\begin{array}{l}-0.34 \\
(0.18)\end{array}$ & $\begin{array}{l}-0.21 \\
(0.12)\end{array}$ & $\begin{array}{l}-0.11 \\
(0.08)\end{array}$ & $\begin{array}{l}-0.18 \\
(0.12)\end{array}$ & $\begin{array}{l}-0.13 \\
(0.12)\end{array}$ & $\begin{array}{l}-0.13 \\
(0.08)\end{array}$ \\
\hline $\begin{array}{l}\text { Education of household } \\
\text { head (years) }\end{array}$ & $\begin{array}{l}0.07 \\
(0.05)\end{array}$ & $\begin{array}{l}0.12 \\
(0.08)\end{array}$ & $\begin{array}{l}0.16^{* *} \\
(0.07)\end{array}$ & $\begin{array}{c}0.09 \\
(0.08)\end{array}$ & $\begin{array}{l}0.08 \\
(0.06)\end{array}$ & $\begin{array}{l}0.16^{* *} \\
(0.08)\end{array}$ & $\begin{array}{l}0.10 \\
(0.06)\end{array}$ & $\begin{array}{l}0.11^{* *} \\
(0.05)\end{array}$ \\
\hline $\begin{array}{l}\text { Poverty status (Above } \\
\text { poverty line) }\end{array}$ & $\begin{array}{l}0.09 \\
(0.07)\end{array}$ & $\begin{array}{l}-0.11 \\
(0.02)\end{array}$ & $\begin{array}{l}0.16 \\
(0.07)\end{array}$ & NA & NA & $\begin{array}{l}0.02 \\
(0.01)\end{array}$ & $\begin{array}{l}0.03 \\
(0.02)\end{array}$ & $\begin{array}{l}0.02 \\
(0.01)\end{array}$ \\
\hline Extension visit & $\begin{array}{l}-0.06 \\
(0.05)\end{array}$ & $\begin{array}{l}0.12 \\
(0.08)\end{array}$ & $\begin{array}{l}-0.05 \\
(0.04)\end{array}$ & $\begin{array}{l}0.09 \\
(0.09)\end{array}$ & $\begin{array}{l}-0.07 \\
(0.05)\end{array}$ & $\begin{array}{l}0.05 \\
(0.03)\end{array}$ & $\begin{array}{l}-0.02 \\
(0.01)\end{array}$ & $\begin{array}{l}-0.05 \\
(0.02)\end{array}$ \\
\hline $\begin{array}{l}\text { Membership to farmer } \\
\text { group }\end{array}$ & $\begin{array}{l}0.20 \\
(0.18)\end{array}$ & $\begin{array}{l}0.13 \\
(0.12)\end{array}$ & $\begin{array}{c}0.07 \\
(0.02)\end{array}$ & $\begin{array}{c}0.11 \\
(0.08)\end{array}$ & $\begin{array}{l}0.16 \\
(0.08)\end{array}$ & $\begin{array}{l}0.06 \\
(0.04)\end{array}$ & $\begin{array}{l}0.27^{* *} \\
(0.14)\end{array}$ & $\begin{array}{l}0.13^{* *} \\
(0.07)\end{array}$ \\
\hline Obtained credit & $\begin{array}{l}0.16 \\
(0.02)\end{array}$ & $\begin{array}{c}-0.11 \\
(0.11)\end{array}$ & $\begin{array}{l}0.52^{* *} \\
(0.25)\end{array}$ & $\begin{array}{l}0.27 \\
(0.26)\end{array}$ & $\begin{array}{l}-0.09 \\
(0.05)\end{array}$ & $\begin{array}{l}0.33 \\
(0.23)\end{array}$ & $\begin{array}{c}-0.09 \\
(0.07)\end{array}$ & $\begin{array}{l}0.07 \\
(0.05)\end{array}$ \\
\hline $\begin{array}{l}\text { Household size (Adult } \\
\text { equivalent) }\end{array}$ & $\begin{array}{c}0.14 \\
(0.10)\end{array}$ & $\begin{array}{l}0.20^{* *} \\
(0.08)\end{array}$ & $\begin{array}{c}0.14 \\
(0.08)\end{array}$ & $\begin{array}{c}0.07 \\
(0.06)\end{array}$ & $\begin{array}{l}0.26^{* * *} \\
(0.08)\end{array}$ & $\begin{array}{c}0.12 \\
(0.10)\end{array}$ & $\begin{array}{l}0.16^{* *} \\
(0.07)\end{array}$ & $\begin{array}{l}0.16^{* * *} \\
(0.06)\end{array}$ \\
\hline Agricultural land (ha) & $\begin{array}{l}0.07^{* *} \\
(0.04)\end{array}$ & $\begin{array}{c}0.03 \\
(0.03)\end{array}$ & $\begin{array}{l}-0.04 \\
(0.01)\end{array}$ & $\begin{array}{l}0.02 \\
(0.02)\end{array}$ & $\begin{array}{c}0.02 \\
(0.02)\end{array}$ & $\begin{array}{c}0.04 \\
(0.01)\end{array}$ & $\begin{array}{l}0.03 \\
(0.02)\end{array}$ & $\begin{array}{l}0.03 \\
(0.02)\end{array}$ \\
\hline Distance to market (km) & $\begin{array}{c}0.04 \\
(0.01)\end{array}$ & $\begin{array}{l}-0.04 \\
\quad(0.03)\end{array}$ & $\begin{array}{l}-0.03 \\
(0.03)\end{array}$ & $\begin{array}{l}0.04 \\
(0.01)\end{array}$ & $\begin{array}{l}-0.07^{* *} \\
(0.03)\end{array}$ & $\begin{array}{c}-0.04 \\
(0.03)\end{array}$ & $\begin{array}{l}-0.06 \\
(0.03)\end{array}$ & $\begin{array}{l}-0.05^{* *} \\
(0.02)\end{array}$ \\
\hline Chi-square & 16.30 & $42.56^{* * *}$ & $22.03^{* * *}$ & $18.53^{* *}$ & $32.07^{* * *}$ & $21.65^{\star *}$ & $31.70^{* * *}$ & $46.06^{* * *}$ \\
\hline Log likelihood & -28.38 & -88.81 & -33.23 & -55.98 & -115.68 & -85.76 & -87.03 & -176.44 \\
\hline $\mathrm{R}^{2}$ & 0.2231 & 0.1933 & 0.2490 & 0.1420 & 0.1217 & 0.1121 & 0.1541 & 0.1155 \\
\hline
\end{tabular}

$* * p<.05 ; * * * p<.01$; standard errors of coefficients of marginal effects are in parentheses.

Notes: (1) NA indicates not applicable; (2) the significance levels relate to comparisons across rows.

Source: Uganda Bureau of Statistics, 2010b.

Education improved the likelihood of adopting improved storage structures. The present findings indicate that the probability of using improved storage structure is correlated with the level of education of the household head; an increase by one year increased the probability of using improved storage technology by $16 \%$ for Apac district, $11 \%$ in both study districts, as well as for households growing finger millet and beans (Table 5). Similar results were found in studies of the adoption of improved storage structures for maize in Benin (Adegbola et al., 2011, cited in Affognon et al., 2015), and metallic grain silos in Malawi (Maongo et al., 2013). There is no doubt that education improves the rate at which new techniques and skills can be absorbed and applied by farmers, and this might explain increasing adoption rates as years of education increase.

Membership in a farmers' group or association improved the probability of household use of improved storage structures by $27 \%$ in Arua and $13 \%$ across both study districts (Table 5). This agrees with findings from previous adoption studies of improved granaries for maize in Mozambique (Cunguara \& Darnhofa, 2011). This might be an indication that organized farmers are empowered (including enhanced diffusion of knowledge and information about new technologies) and have improved bargaining power for cost-effective technology acquisition compared to their counterparts 
(Okorley, Adjargo, \& Bosompem, 2014). Adoption by group members might also be due to peer pressure (Lwala et al., 2016; Malima, Blomquist, Olson, \& Schmitt, 2014).

Household size increased the probability of using improved storage structures. An increase in household size by one adult equivalent increased the probability of using improved storage structure by $26 \%$ for households below the poverty line, $20 \%$ for those growing beans, and 16\% for households in Apac and Arua districts (Table 5). Similar results were obtained by a study investigating the adoption of improved storage technologies for fresh yam in Benin (Adegbola et al., 2003 cited in Affognon et al., 2015), and a study of the effect of farmer field schools on adoption of technologies in eastern Uganda (Lwala et al., 2016). Construction of improved storage structures often requires intensive labor, and family labor is a major source of on-farm labor in developing countries. In most developing countries in the past, the people residing in a village were more or less an extended family and therefore could assist each other for most of the activities. However, with the recent increase in rural-urban migration in a number of developing countries by those in search of better employment opportunities and an improved standard of living, a number of rural families have lost massive family/village labor resources. This accelerated rural-urban migration to urban areas, particularly by youth, has escalated labor costs for agriculture in the rural areas; this is certainly the case in Uganda, with possible impact on the adoption of intensive labor technologies in agriculture, including for postharvest technologies

(Government of Uganda, 2015).

The distance of a household from the nearest local produce market was negatively associated with use of improved storage structure. An increase in distance from a household to the local produce market of one kilometer (0.6 mile) reduced the probability of use of improved storage technology by $7 \%$ for households below the poverty line and by 5\% for those in Apac and Arua districts (Table 5). Similarly, market-oriented maize farmers in Benin, with better access to market, were found to more easily adopt improved storage structures (Adegbola et al., 2011 cited in Affognon et al., 2015). Reduced market access associated with an increase in distance to the market makes households less market-oriented in their production decisions, leading to low marketable surpluses for storage. This may be due to limited awareness of the advantages of using improved storage structures, such as reduced postharvest losses, as well as low access to postharvest storage technologies in the rural areas of Uganda largely due to credit constraints (Government of Uganda, 2015).

The sex of the household head and size of agricultural land were significant only for households growing finger millet (Table 5). Femaleheaded households growing finger millet were $49 \%$ more likely to adopt improved storage structures than their male counterparts (Table 5), probably due to the associated advantages of reduced postharvest losses for improved food security and commercial purposes (WFP, 2015). As shown in Table 5 , an increase in agricultural land by one hectare $(2.47$ acres $)$ improved the likelihood of household adoption of improved storage structures by $7 \%$, likely due to better possession of financial resources to hire farm labor and increased millet output, in line with results obtained by a study by UBOS (2010b). Contrary to a priori expectations, income of household (poverty status) and access to extension did not seem to explain the use of improved storage structures by households in Apac and Arua districts. Poor access to extension service, as shown in Table 1 above, could be one of the plausible reasons.

\section{Conclusions}

This study has revealed that a majority of households in Uganda still use unimproved storage structures for conserving agricultural produce. This seems to suggest that past postharvest policies and interventions have not yet had a significant effect on enhancing the use of improved storage structures by households in Apac and Arua districts. While age of household head, education of household head, membership in a farmer group or association by household head, access to credit, family size, and distance of the household to a local produce market influenced household usage of improved storage structures, household income and access to extension service did not. It is thus 
appropriate to maintain and accelerate the mobilization and organization of households into farmer groups or associations as one of the important vehicles for making farmers aware of the benefits of improved postharvest storage structures, due to the positive effect of membership in farmer groups or associations on use of these technologies. Support to rural farmers' education in the context of rural development could lead to increased farmer access to knowledge and information that are beneficial to facilitating postharvest technologies, as demonstrated by results of analysis in this study. Enhancing market access by increasing the number of rural markets equipped with appropriate facilities that meet quality standards for food safety would enhance market access for farmers and use of improved storage structures by households. Support to increase household access to credit would also promote adoption of improved postharvest storage structures. However, future research needs to examine the benefits and costs associated with various on-farm storage structures. Knowledge of farmer perceptions about improved storage structures might also provide a clue as to what extension package should be used to disseminate these technologies.

\section{Acknowledgement}

The authors would like to extend special thanks to Prof. Bernard Bashaasha, principal of the College of Agricultural and Environmental Sciences, Makerere University, Kampala, for his useful comments and support. We also thank the various anonymous JAFSCD reviewers and the Uganda Bureau of Statistics for providing the agricultural census 2008/09 dataset.

\section{References}

Abass, A. B., Ndunguru, G., Mamiro, P., Alenkhe, B., Mlingi, N., \& Bekunda, M. (2014). Post-harvest food losses in a maize-based farming system of semi-arid savannah area of Tanzania. Journal of Stored Products Research, 57, 49-57. https://doi.org/10.1016/j.jspr.2013.12.004

Adegbola, P. Y. (2010). Economic analyses of maize storage innovations in southern Benin. (Unpublished doctoral dissertation). Wageningen University, Wageningen, Netherlands.
Adetunji, M. O. (2009). Profitability evaluation of maize storage techniques by farmers and traders in Kwara State, Nigeria. Journal of Food Products Marketing, 15(4), 392-405. https://doi.org/10.1080/10454440802537280

Affognon, H., Mutungi, C., Sanginga, P., \& Borgemeister, C. (2015). Unpacking postharvest losses in sub-Saharan Africa: A meta-analysis. World Development, 66, 49-68. https://doi.org/10.1016/j.worlddev.2014.08.002

Arouna, A., Adegbola, P. Y., \& Biaou, G. (2011). Analyse des coûts de stockage et de conservation du maïs au Sud-Bénin [Analysis of the costs of storage and conservation of maize in South Benin]. Bulletin de la Recherche Agronomique du Bénin, Numero spécial 2, 13-23. Retrieved from http://www.slire. net/download/618/article2 brab sp cial 2 sept$2011 \mathrm{ma} \mathrm{s}$ arouna et al analyse co ts stockage conservation.pdf

Bediako, J. A., Chianu, J. N., \& Dadson, J. A. (2009). Crop storage efficiency and market competitiveness: Case of groundnut and cowpea in Ghana. African Journal of Marketing Management, 1(3), 81-88. Retrieved from the Academic Journals website: http://www.academicjournals.org/journal/AJMM/ article-abstract/7EB6AD51923

Bouquet, E., Wampfler, B., \& Ralison, E. (2009). Rice inventory credit in Madagascar: Conditions of access and diversity of rationales around an bybrid financial and marketing service. Retrieved from the Microfinance Gateway website: http://www.microfinancegate way.org/library/rice-inventory-credit-madagascarconditions-access-and-diversity-rationales-aroundhybrid

Chauvin, N. D., Mulangu, F., \& Porto, G. (2012). Food production and consumption trends in sub-Saharan Africa: Prospects for the transformation of the agricultural sector (Working Paper 2012-011). Retrieved from the United Nations Development Programme website: http://www.africa.undp.org/content/rba/en/hom e/library/working-papers/food-productionconsumption-trends.html

Coulter, J. \& Onumah, G. (2002). The role of warehouse receipt systems in enhanced commodity marketing and rural livelihoods in Africa. Food Policy, 27(2002), 319-337. Retrieved from http://www.elsevier.com/locate/foodpol 
Cunguara, B., \& Darnhofer, I. (2011). Assessing the impact of improved agricultural technologies on household income in rural Mozambique. Food Policy, 36(3), 378-390. https://doi.org/10.1016/i.foodpol.2011.03.002

Food and Agriculture Organization of the United Nations [FAO]. (2011). Global food losses and food waste: Extent, causes and prevention. Retrieved from http://www.fao.org/docrep/014/mb060e/ mb060e00.pdf

FAO. (2015). Regional overview of food insecurity: African food security prospects brighter than ever. Retrieved from http://www.fao.org/3/a-i4635e.pdf

Golob, P. (1991). Evaluation of the campaign to control larger grain borer, Prostephanus truncatus in western Tanzania. FAO Plant Protection Bulletin, 39, 65-71.

Government of Uganda. (2015). Second National Development Plan (NDPII), 2015/16-2019/20. Retrieved from http://npa.ug/wp-content/ uploads/NDPII-Final.pdf

Greene, W. H. (1997). Econometric analysis (3rd ed.). Upper Saddle River, New Jersey: Prentice Hall.

Hodges, R. J., Buzby, J. C., \& Bennett, B. (2011). Postharvest losses and waste in developed and less developed countries: Opportunities to improve resource use. Journal of Agricultural Science, 149(S1), 37-45. https://doi.org/10.1017/S0021859610000936

Jones, M. S., \& Lowenberg-DeBoer, J. (2014). Updating ex-ante economic analyses for Purdue Improved Crop Storage (PICS) bags in sub-Saharan Africa: The cases of Senegal, Kenya and Ghana (Working Paper No. 14-5). http://purl.umn.edu/177529

Kankolongo, M. A., Hell, K., \& Nawa, I. N. (2009). Assessment for fungal, mycotoxin and insect spoilage in maize stored for human consumption in Zambia. Journal of the Science of Food and Agriculture, 89(8), 1366-1375. https://doi.org/10.1002/jsfa.3596

Kenya National Federation of Agricultural Producers [KENFAP]. (2011). The role of warehouse receipt system and financial services in improving produce marketing by smallholders in Kenya. Retrieved from http://www.esfim.org/wp-content/uploads/ ESFIM-Case-Studies-WRS-REPORT-Sharedduring-the-validation-workshop.pdf

Kereth, G. A., Lyimo, M., Mbwana, H. A., Mongi, R. J., \& Ruhembe, C. C. (2013). Assessment of post- harvest handling practices: Knowledge and losses of fruits in Bagamoyo District of Tanzania. Food Science and Quality Management, 11, 8-15. Retrieved from http://www.iiste.org/Journals/index.php/ FSQM/article/view/3951

Lapar, M. L. A., \& Pandey, S. (1999). Adoption of soil conservation: The case of the Philippine uplands. Agricultural Economics, 21(3), 241-256.

Lwala, R. J., Elepu, G., \& Hyuha, T. S. (2016). Effect of farmer field school on adoption of improved cotton production technologies in Eastern Uganda. Journal of Agricultural Economics, Extension and Rural Development, 4(4), 419-428. Available from http://www.springjournals.net/jaeerd/spring journals.netjaeerdarticlesindex $=91$ walaetal

Malima, G., Blomquist, R., Olson, K., \& Schmitt, M. (2014). The Companion Village Project: An extension education tool for improving crop production. Journal of International Agricultural Extension Education, 21(1), 19-32. https://www.aiaee.org/

Maonga, B. B., Assa, M. M., \& Haraman, E. M. K. (2013). Adoption of small metallic grain silos in Malawi: A farm level cross-sectional study. International Journal of Development and Sustainability, 2(2), 1534-1548. https://isdsnet.com/ijds.html

Moussa, B., Lowenberg-DeBoer, J., Fulton, J., \& Boys, K. (2011). The economic impact of cowpea research in West and Central Africa: A regional impact assessment of improved cowpea storage technologies. Journal of Stored Products Research, 47(3), 147-156. https://doi.org/10.1016/j.jspr.2011.02.001

Mukiibi, J. K. (Ed.). (2001). Agriculture in Uganda: Vol. 1: General information. Kampala, Uganda: Fountain Publishers.

Mutambuki, K., \& Ngatia, C. M. (2006). Loss assessment of on-farm stored maize in semi-arid area of Kitui district, Kenya. In I. Lorini, B. Bacaltchuk, H. Beckel, D. Deckers, E. Sundfeld, J. P.dos Santos, J. D.,...V. M. Scussel (Eds.), Proceedings of the $9^{\text {th }}$ International Working Conference on Stored Products Protection (PS1-16318) held October 15-18, 2006, in Sao Paulo, Brazil. Retrieved from http://spiru.cgahr.ksu.edu/proj/ iwcspp/pdf2/9/6318.pdf

Obeng-Ofori, D. (2011). Protecting grain from insect pest infestations in Africa: Producer perceptions and practices. Stewart Postharvest Review, 7(3), 1-15. 
Okoedo-Okojie, D. U., \& Onemolease, E. A. (2009). Factors affecting the adoption of yam storage technologies in the northern ecological zone of Edo State, Nigeria. Journal of Human Ecology, 27(2), 155160. Retrieved from http://www.krepublishers.com

Okorley, E. L., Adjargo, G., \& Bosompem, M. (2014). The potential of Farmer Field School in cocoa extension delivery: A Ghanaian case study. Journal of International Agricultural Extension Education, 21(2), 32-44. Retrieved from https://www.aiaee.org/ index.php/vol-21-2-summer-14/1598-thepotential-of-farmer-field-school-in-cocoaextension-delivery-a-ghanaian-case-study

Onumah, G. (2010, September). Implementing warehouse receipt systems in Africa: Potential and challenges. Paper prepared for the Fourth African Agricultural Markets Program Policy Symposium, Lilongwe, Malawi. Retrieved from http:// fsg.afre.msu.edu/aamp/

Pindyek, R. S., \& Rubinfeld, D. L. (1991). Econometric models and economic forecasts. New York: McGraw-Hill.

Republic of Uganda, Ministry of Agriculture, Animal Industry and Fisheries [MAAIF]. (2012a). Operationalization of the non-ATAAS component of the Development Strategy and Investment Plan: Analytical report (grains). Kampala, Uganda: Author.

Republic of Uganda, MAAIF. (2012b). Analytical report of the agricultural mechanisation taskforce. Kampala, Uganda: Author.

Republic of Uganda, Ministry of Finance, Planning and Economic Development [MFPED]. (2014). Uganda Poverty Status Report 2014: Structural change and poverty reduction in Uganda. Available from http://www.ug. undp.org/content/uganda/en/home/library/huma n_development/TheUgandaPovertyStatusReport20 14.html

Ssewanyana, S., \& Kasirye, I. (2010). Food insecurity in Uganda: A dilemma to achieving the hunger Millennium Development Goal (Research Series No. 70). http://purl.umn.edu/113614

Stathers, T., Lamboll, R., \& Mvumi, B. M. (2013). Postharvest agriculture in changing climates: Its importance to African smallholder farmers. Food Security, 5(3), 361-392. https://doi.org/10.1007/s12571-013-0262-z

Thamaga-Chitja, J. M., Hendriks, S. L., Ortmann, G. F., \& Green, M. (2004). Impact of maize storage on rural household food security in Northern KwazuluNatal. Journal of Family Ecology and Consumer Sciences, 32, 8-15. Retrieved from http://www.ajol.info/ index.php/ifecs/article/viewFile/52843/41445

Ton, G., de Grip, K., Lançon, F., Onumah, G. E., \& Proctor, F. J. (2014). Empowering smallholder farmers in markets: Strengthening the advocacy capacities of national farmer organisations through collaborative research. Food Security, 6(2), 261-273. https://doi.org/10.1007/s12571-014-0339-3

Uganda Bureau of Statistics [UBOS]. (2010a). Uganda Census of Agriculture, 2008/2009: Volume IIMethodology report. Retrieved from http://www.fao.org/fileadmin/templates/ess/ ess_test_folder/World_Census_Agriculture/ Country info 2010/Reports/Methodology 4/ UGA ENG MET 2008-09.pdf

Uganda Bureau of Statistics. (2010b). Uganda Census of agriculture, 2008/2009: Volume III-Agricultural bousehold and holding characteristics report. Retrieved from http://www.ubos.org/onlinefiles/uploads/ ubos/pdf documents/UCAholding.pdf

Uganda Bureau of Statistics. (2013). 2013 statistical abstract. Kampala, Uganda: Ministry of Finance \& Economic Development.

United Nations. (n.d.). About MDGs: What they are. Retrieved February 21, 2017, from http://www.unmillenniumproject.org/goals/

United Nations. (2015). The Millennium Development Goals report 2015: Regional backgrounder: Sub-Saharan Africa. Retrieved from http://www.un.org/millennium goals/2015 MDG Report/pdf/backgrounders/ MDG $\% 202015 \% 20 \mathrm{PR} \% 20 \mathrm{Bg}^{0} \% 20 \mathrm{SSA}$.pdf

U.S. Agency for International DevelopmentLivelihoods and Enterprises for Agricultural Development [USAID-LEAD]. (2012, September). Proceedings of July 12 stakeholder event to understand and address issues to increase utilization of UCE-licensed warehouses in Uganda. Kampala, Uganda: Author.

Winniefridah, M., \& Manuku, M. (2013). Traditional science of seed and crop yield preservation: Exploring the contribution of women to indigenous knowledge systems in Zimbabwe. International Journal of Humanities and Social Science, 3(4), 234-245. Retrieved from http://www.ijhssnet.com/ 
Woomer, P. L., \& Mukhwana, E. J. (2004). Working with smallholder farmers to improve maize production and marketing in western Kenya. Uganda Journal of Agricultural Sciences, 9, 491-500. Retrieved from http://www.ajol.info/index.php/ujas/

World Bank, The. (2011). Missing food: The case of postharvest grain losses in sub-Saharan Africa. (Report No. 60371-AFR). Washington, D.C.: Author.
World Food Programme of the United Nations [WFP]. (2015). Reducing food losses in sub-Sabaran Africa (improving post-harvest management and storage technologies of smallholder farmers): An 'Action Research' evaluation trial from Uganda and Burkina Faso. Retrieved from http://documents.wfp.org/stellent/groups/public/ documents/special initiatives/WFP265205.pdf

World Health Organization [WHO]. (1985). Energy and protein requirements (WHO Technical Report Series No. 724). Geneva, Switzerland: Author. 